\title{
The role of two- and three-dimensional transesophageal echocardio- graphy in the treatment of patients with patent foramen ovale
}

\author{
Sandra Jakšić \\ Jurinjak', \\ Josip Vincelj', \\ Mateja Sabol Pušić2 ${ }^{*}$, \\ Mario Sičaja', \\ Boris Starčević
}

'University Hospital Dubrava, Zagreb, Croatia

${ }^{2}$ County Hospital Čakovec,

Čakovec, Croatia

\section{RECEIVED:}

March 11, 2017

ACCEPTED:

April 6, 2017

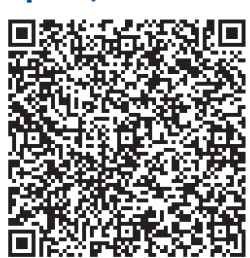

Cardiologia Croatica 2017;12(4):156.
KEYWORDS: transesophageal echocardiography, patent foramen ovale.

CITATION: Cardiol Croat. 2017;12(4):156. | https://doi.org/10.15836/ccar2017.156

*ADDRESS FOR CORRESPONDENCE: Mateja Sabol Pušić, Županijska bolnica Čakovec, UI. Ivana Gorana Kovačića $1 E$, HR-40000 Čakovec, Croatia. / Phone: +385-98-908-3512 / E-mail: matejasm@gmail.com

ORCID: Sandra Jakšić Jurinjak, http://orcid.org/0000-0002-7349-6137 • Josip Vincelj, http://orcid.org/0000-0003-0064-9128 Mateja Sabol Pušić, http://orcid.org/0000-0003-4895-0681 • Mario Sičaja, http://orcid.org/0000-0003-0773-4720 Boris Starčević, http://orcid.org/0000-0002-3090-2772

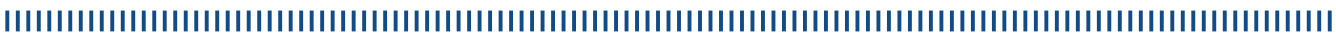

Introduction: Patent foramen ovale (PFO) is a defect of the interatrial septum usually with no clinical repercussions, incidence of about $25 \%$, but can also be associated with various clinical conditions such as cryptogenic stroke, migraine, platypnea-orthodeoxia syndrome, and decompression illness ${ }^{1}$. Recent studies have demonstrated that transcatheter closure of such defects is a safe procedure with long term efficacy in preventing paradoxical embolism. Transesophageal echocardiography (TEE) is pivotal in diagnosing PFO with precise characterization of septal abnormalities, selection of patients suited for transcatheter closure, but also for guidance during the intervention, assessment of intervention and as appropriate method for follow up, especially in case of a residual shunt after the intervention ${ }^{2}$

Case report: We describe the significance and role of two and three dimensional (2D and 3D) transesophageal echocardiography performed in series of five patients diagnosed with cryptogenic stroke and concomitant PFO who underwent transcatheter closure. TEE was performed during and after transcatheter closure (Figure 1), both PFO diameter and morphology were assessed by TEE before transcatheter closure. Right-to-left interatrial shunting was assessed by contrast TEE facilitated with Valsalva's maneuver. During transcatheter closure, TEE was used for guidance and positioning of the Amplatzer occluder. Immediate complete closure was documented by color Doppler TEE. All patients received antibiotic prophylaxis 1 hour prior to the procedure. After post-interventional transthoracic echocardiography with early success of closure tested by a venous injection of right heart echo contrast agent patients were discharged.

Conclusion: Some studies showed that the success of the procedure - transcatheter closure, with the goal being complete occlusion without any residual shunt, is more dependent on the anatomy of the atrial septum than the type of the device used for the procedure ${ }^{3}$. Therefore, also in our opinion, 2D and 3D echocardiographic assessment, initially in patient selection and afterwards during the intervention, is crucial for the successful treatment.
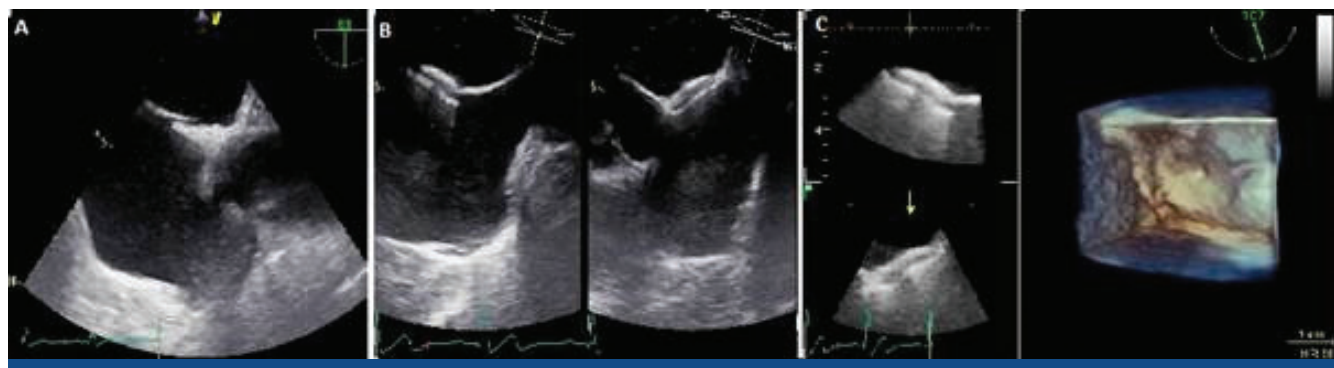

FIGURE 1. A) Transesophageal image of simple PFO; B) Transcatheter closure - transesophageal echocardiography was used for guidance and positioning of the Amplatzer occluder (multiplane view); C) 3D transesophageal image of occluder positioned in interatrial septum.

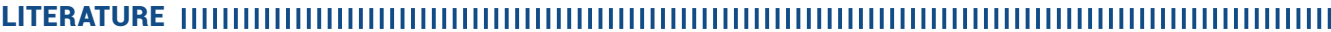

Hernández-Enríquez M, Freixa X. Current indications for percutaneous closure of patent foramen ovale. Rev Esp Cardiol (Engl Ed). 2014 Aug;67(8):603-7. https://doi.org/10.1016/j.rec.2014.01.008

2. Silvestry FE, Cohen MS, Armsby LB, Burkule NJ, Fleishman CE, Hijazi ZM, et al; American Society of Echocardiography: Society for Cardiac Angiography and Interventions. Guidelines for the Echocardiographic Assessment of Atrial Septal Defect and Patent Foramen Ovale: From the American Society of Echocardiography and Society for Cardiac Angiography and Interventions. J Am Soc Echocardiogr. 2015 Aug;28(8):910-58. https://doi.org/10.1016/j.echo.2015.05.015

3. Vitarelli A, Mangieri E, Capotosto L, Tanzilli G, D'Angeli I, Toni D, et al. Echocardiographic findings in simple and complex patent foramen ovale before and after transcatheter closure. Eur Heart J Cardiovasc Imaging. 2014 Dec;15(12):1377-85. https://doi.org/10.1093/ehjci/jeu143 